\title{
THE CONCEPT OF THE MILLET IN TURKISH DICTIONARIES: ITS ALTERATION AND THE IMPACT ON OTTOMAN MACEDONIA
}

\author{
MARIA PANDEVSKA, MAKEDONKA MitRova
}

\begin{abstract}
The Concept of the Millet in Turkish Dictionaries: Its Alteration and the Impact on Ottoman Macedonia.

In the $19^{\text {th }}$ century the dictionaries/glossaries represent the first brace which connected different cultures and languages, thus also linking the Orient with the Occident and vice versa. In this context the research is focused on the Turkish dictionaries/glossaries, which for a long time actually represented one of the basic media of transmitting the new Western ideas in the East, and in our case, in the Ottoman Empire. Through the short comparative analyses of these dictionaries/glossaries and their authors (from the $19^{\text {th }}$ century and early $20^{\text {th }}$ century) we follow the change of the cognitive concept of the term millet with the term nation. The case study is focused on Ottoman Macedonia and on the political implications caused by this change of the meaning of the Ottoman term millet.
\end{abstract}

STRESZCZENIE. W XIX wieku słowniki/glosariusze stanowiły pierwszą klamrę, która łączyła różne kultury i języki, łącząc w ten sposób także Orient z Zachodem i vice versa. W tym kontekście badania koncentrują się na tureckich słownikach / glosariuszach, które przez długi czas faktycznie stanowiły jeden z podstawowych środków przekazu nowych zachodnich idei na Wschodzie, a w naszym przypadku w Imperium Osmańskim. Poprzez krótkie analizy porównawcze tych słowników/glosariuszy i ich autorów (z XIX i początku XX wieku) śledzimy przemiany koncepcji znaczeniowej pojęcia millet $\mathrm{w}$ kierunku pojęcia naród. Studium przypadku koncentruje się na osmańskiej Macedonii i politycznych implikacjach spowodowanych tą zmianą znaczenia osmańskiego terminu millet.

\section{Authors:}

Maria Pandevska, Institute of National History, Ss. Cyril and Methodius University, Gligor Prlicev 3, Skopje, North Macedonia, e-mail: mariamanol@hotmail.com

Makedonka Mitrova, Institute of National History, Ss. Cyril and Methodius University, Gligor Prlicev 3, Skopje, North Macedonia, e-mail: m.mitrova@yahoo.com

Keywords: Ottoman Empire, millet, nation, Ottoman Balkan, Ottoman Macedonia, Turkish dictionaries/glossaries

Słowa kluczowe: imperium osmańskie, millet, naród, osmańskie Bałkany, osmańska Macedonia, słowniki tureckie, glosariusze tureckie

Balcanica Posnaniensia. Acta et studia, XXVI, Poznań 2019, Wydawnictwo Instytutu Historii UAM, pp. 171192, ISBN 978-83-66355-32-3, ISSN 0239-4278. English text with summaries in English and Polish.

doi.org/10.14746/bp.2019.26.7 


\section{INTRODUCTION}

The usage of the term millet in the Ottoman Empire in the $19^{\text {th }}$ and in the beginning of the $20^{\text {th }}$ century, encompassed only the terms faith and or religion; or in a broader sense religious community, or a community of people of the same faith. From their perspective, the Ottoman authorities named the entire population in the Empire only according to its millet affiliation, without imposing any national connotation to it. ${ }^{1}$ This fact has also been confirmed by leading contemporary Orientalists. ${ }^{2}$ Thus, at a first glance it may seem that this issue has already been clarified both from a historical and linguistic point of view. ${ }^{3}$ However, that is the case if we only consider the Oriental studies in general. Yet, in relation with most of the Balkan contemporary historiography works ((on the historical period of the 19th and early 20th century in Ottoman Macedonia) there are still many scholarly texts which equate the term millet not with faith or religion, but with the term nation. These authors are mostly (but not exclusively) from the Balkans. Without listing the vast number of these works (which would burden this text enormously), it can only be pointed out that, to this day, the historiography of the neighboring countries to Ottoman Macedonia treat the Balkan Wars (1912-1913) only as "liberating wars". On the one hand, the adjective "liberating" could cover the "Christian solidarity" of the armed interventions of the First Balkan War, but on the other hand that same "Christian solidarity" cannot explain the core of the Second Inter-Christian Balkan War.

Throughout all these historiography texts the use of the term "liberating" for the Balkan Wars (1912-1913), explicitly favors the existence of the equation "millet = na-

${ }^{1}$ For example, in the Ottoman Empire's censuses from the first decades of the $19^{\text {th }}$ century, as well as the census from 1831, the term "Bulgarian" cannot be found, because at this time the Bulgarian Exarchate did not still exist, while all the Balkan Christians, subjects of the Empire, were dubbed by the term "Greek Orthodox" precisely Rum. However, the Ottoman administration at that time had a different name in the cases of Gypsies, Jews and Armenians. See: S.J. Shaw, The Ottoman Census System and Population, 1831-1914, ,International Journal of Middle East Studies” 1978, vol. 9, no 3, p. 326.

2 B. Lewis, The Political Language of Islam, Chicago 1988, p. 58; K. F. Schull, Identity of the Ottoman Prison Surveys of 1912 and 1914, „International Journal of Middle East Studies” 2009, vol. 41, no 3, p. 365-367; Christians and Jews in the Ottoman Empire: Functioning of a Plural Society: The Central Lands, eds. B. Broude and B. Lewis, New York-London 1982; E. Aviv, Millet System in the Ottoman Empire, Oxford, http://www.oxfordbibliographies.com/view/document/obo-9780195390155/ obo-9780195390155-0231.xml [access: 08.09.2017].

${ }^{3}$ The word milla, which is better known in its Turkish form- millet, is in fact an Arabian word from the Koran, with an Aramaic origin, and its original meaning is word. This term expanded from its basis into the Islamic understanding as a group of people who respect their unique Holy book/word. Thus, the Muslim millet covered the whole Muslim population of the empire and even abroad; the Jewish millet consisted of the Jews in the empire; the Armenian millet was comprised of the Armenians; the Catholic millet referred to the Catholic Christians, and the Rum millet included the Orthodox population, which until 1870 was under jurisdiction of the Constantinople Patriarchy. During the first decades of the 19th century this word began to be westernized by the Western Orientalists, and thus at the time was equated with the word nation. In this article our colleague, Professor d-r Dragi Gjorgiev (from the Institute of National History) translated parts of the glossaries of the Oriental languages. 
tion". From there it can be understood that in Ottoman Macedonia the Balkan states "liberated" their "brothers" - the "Greeks", "Serbs" and "Bulgarians". The historiography of the RM (PRM/SRM/RNM) ${ }^{4}$ tries to contradict this historic interpretation of the liberating character of these wars. The discourse of the Macedonian historiography is based on historical sources which claim that in the period of the late $19^{\text {th }}$ and early $20^{\text {th }}$ century (even with various exogenous and endogenous labeling or selfnaming) the process of the formation of a separate indigenous Macedonian nation had begun in Ottoman Macedonia. ${ }^{5}$ The Macedonian population was located within different millets in the Ottoman administration - the Rum millet (and its Serbian branch), the Bulgarian millet, but also in the frame of the Muslim millet. ${ }^{6}$ The $19^{\text {th }}$ century was also the period when the formation of the Balkan nations and the national states occurred, together with the beginning of their pretensions for territorial expansion toward the Ottoman Empire.

Because of all these essential differences of the interpretation of the term millet, this research focuses on the Turkish dictionaries/glossaries of the $19^{\text {th }}$ and early $20^{\text {th }}$ century as authentic historical source materials. The millet system was one of the pillars of the social and legal system and it determined some of the rights and duties of both the Muslim and non-Muslim population in the empire. When the equivalence "millet = nation" was introduced in the Western dictionaries, it had a substantial impact on the territory of Ottoman Macedonia and would lead to significant changes in the perception of its ethnic structure.

We have narrowed down the focus of this very broad topic:

1) In this article we will not look into the phases of transformation of the millet system, before and after the period of the Tanzimat, neither will we review the role of this community system, which enabled some peoples under Ottoman domina-

\footnotetext{
${ }^{4}$ RM - Republic of Macedonia in UN under the reference FYROM. PRM - People's Republic of Macedonia and SRM - Socialistic Republic of Macedonia during the period of Tito's Yugoslavia and forthcoming - Republic North Macedonia.

${ }^{5}$ М. Пандевски, Македонското ослободително дело во ХІХ и ХХ век. Националното прашање во македонското ослободително движење 1893-1903, Skopje 1987; M. Pandevska, The Term Macedonian(s) in Ottoman Macedonia: On the Map and in the Mind, „Nationalities Papers. The Journal of Nationalism and Ethnicity" 2012, vol. 40, no 5, p. 747-766.

${ }^{6}$ The Macedonian national building process with all its particularities went through Miroslav Hroch's phases of the smaller European nations: A, B and C. The 90ties of the $19^{\text {th }}$ and the first decade of the $20^{\text {th }}$ century was phase $\mathrm{B}$ (period of patriotic agitation) together with phase C (the rise of mass national movement) led by the Macedonian Revolutionary Organization (1893-1908) [from 1896. SMORO from 1905. IMORO]. The second stage of phase $\mathrm{C}$ was turbulently interrupted by the Balkan Wars and the First World War, only to have it continue under new circumstances in the period between the two World Wars as well as during and after the Second World War. М. Пандевска, Транзициите во македонското национално-ослободително движење: низ теоријата на Мирослав Хрох, во: Транзициите во историјата и културата, Скопје 2008, p. 171-186; M. Hroch, Social Preconditions of the National Revival in Europe, A Comparative Analysis of the Social Composition of the Patriotic Group among the Smaller European Nations, Cambridge-London-New York 1985.
} 
tion to form a nation sooner than others (the Greeks, the Jews, and at some point the Armenians) ${ }^{7}$.

2) Our article also leaves out the debate about the location of the use of the term millet for the non-Muslim communities. Both authors (Benjamin Broude and Michael Ursinus) agree that the term millet is used for the non-Muslim communities in the Empire in the $19^{\text {th }}$ century (which is the period of our observation). ${ }^{8}$

3) This article focuses on the political implications in the Ottoman Balkan, with the formation of a new Orthodox Church institution and consequently new millet in the empire (the Bulgarian Exarchate and therefore the Bulgarian millet). This was a process parallel to the alteration of the meaning of the term millet i.e. the acceptance of its new interpretation as "millet=nation". Taking Ottoman Macedonia as a case study, we analyze the political implications which took place after the equation "millet=nation" was introduced and used. We will consider the relation between "the Occident and the Orient" as well as their interaction in the process of naming and in the process of interpretation, via the theoretical groundwork of Edward Said.

The literalization of this equation had a negative impact on the development of the Macedonian national building processes in the $19^{\text {th }}$ and the beginning of the $20^{\text {th }}$ century, especially when the Westernization of the censuses took place in the Ottoman Empire. ${ }^{9}$ The differing Orthodox Church affiliation (in the case of Ottoman Macedonia it is not even a matter of faith, but only a matter of church affiliation) were raised (and is still being raised) to the level of a different ethnic or even "national" affiliation. Thus if the members of a single Macedonian family practiced their Orthodox faith in different Orthodox churches, or if they attended different schools, through the equation of "millet=nation", they would be considered as "Serbs, Greeks or Bulgarians" in some type of "national" context. This absurdity can be confirmed trough the basic postulates of Barth's theory about ethnic groups and boundaries. ${ }^{10}$ According to F. Barth, belonging to a church could have been just one of the markers of a certain ethnic group, and it did not necessarily indicate the existence of a different, separate ethnic group per se. ${ }^{11}$

${ }^{7}$ G. Dimitri, I. Charles, Ottoman Greeks in the Age of Nationalism: Politics, Economy and Society in the Nineteenth Century, Princeton 1999; T.H. Papadopoullos, Studies and Documents relating to the history of Greek Church and people under Turkish Domination, 1990; A. Levy, The Jews in the Ottoman Empire, Princeton 1994; M. K. Krikorian, Armenians in the service of the Ottoman Empire 1860-1908, London 1978.

${ }^{8}$ Broude Benjamin, Foundation Myths of the Millet System, Christians and Jews in the Ottoman Empire, in: Christians and Jews in the Ottoman Empire, p. 69-88; M. Ursinus, Zur Diskussion um "Millet" im osmanischen Reich, "SüdostForschungen" 1989, vol. 48, p. 195-207.

${ }^{9}$ Shaw, The Ottoman Census System, p. 325-338; K. H. Karpat, Ottoman Population Records and the Census of 1881/82-1893, „International Journal of Middle East Studies” 1978, vol. 9, no 3, p. 237 274; Yosmaoğlu Ipek, Counting Bodies, Shaping Souls: the 1903 Census and National Identity in Ottoman Macedonia, „International Journal for Middle East Studies” 2006, vol. 38, p. 55-77.

${ }^{10} \mathrm{~F}$. Barth, Ethnic groups and boundaries. The social organization of culture difference, Oslo 1969.

${ }^{11}$ I. D. Michalidis, The War of Statistics: Traditional Recipes for the Preparation of the Macedonian Salad, „East European Quarterly” 1998, vol. 31, no 1, p. 9-12; P. M. Kitromilides, Imagined Communities 
4) In the Balkan parts of the Ottoman Empire in the early $19^{\text {th }}$ century, the areas where the religious and linguistic differences were clearly distinctive (between the Christians and the Muslims on one side, or the Greek, South-Slavic and Albanian languages on the other) determining where one belonged, at first sight seemed relatively easy. However, the question is: where did the meaning of these criteria become a problem? The German historian Holm Sundhaussen finds it in the fluid transitions between the South-Slavic languages of that time. ${ }^{12}$ Our research is based upon the understanding that the Macedonian vernacular, with all of its diversity and peculiarities, was a separate language among the South Slavic group of languages, even before it was codified. We base this postulation on the works of different world renowned linguists: Jan Baudouin de Courtenay (1845-1929), Leonard Mazing (1845-1936), Antoine Meillet (1866-1936), André Mazon (1881-1967), August Leskein (18401916), Filip Fedorovich Fortunatov (1848-1914), and others. ${ }^{13}$

\section{THE DISTINCTIVENESS OF THE MILLET SYSTEM IN THE OTTOMAN MACEDONIA}

The millet system represents a specific system of rule in the Ottoman Empire. The Ottoman millets lived within their own social, cultural and economic milieus and had a great deal of autonomy, which meant that they could set their laws to collect and distribute taxes, as long as they accepted the rule of the Ottoman sultan. ${ }^{14}$ This system warranted the religious rights and freedoms to the Ottoman subjects. Thus, different churches, synagogues, and mosques, as well as their schools, had a limited autonomy regarding the family rights and religion laws in the empire. The millet system emerged gradually as a result of the efforts of the Ottoman administration to take into account the organization and culture of the various religious or ethnic groups it ruled. According to Kemal H. Karpat: "the system provided, on one hand, a degree of religious, cultural, and ethnic continuity with these communities, while on the other, it permitted their incorporation into the Ottoman administrative economic and political system". He further explains: "The community was the basic organizational unit of the millet without which its existence was rather inconceivable. It consisted essentially of people who belonged to the same faith. A community was a religious congregation as much as it was a social and administrative unit. So the community played a major role as a collective representative and repository of local ethnic, cultural, and

and the Origins of the National Question in the Balkans, „European History Quarterly” 1989, vol. 19, p. 149-194.

${ }^{12}$ H. Zundhausen, Istorija Srbije od 19. do 20. veka, Beograd 2009, p. 149.

${ }^{13}$ V.A. Friedman, Macedonian language and nationalism during the nineteenth and early twentieth centuries, „Balkanistica” 1975, vol. 2, p. 83-98; Д. Пандев, Вовед во македонистиката, Скопје 2009.

14 E. F. Asli, The Ottoman Identity: Turkish, Muslim or Rum?, „Middle Eastern Studies” 2012, vol. 48, no 4, p. 629-645. 
linguistic peculiarities... The family was the foundation of the community as well as the chief institution which preserved and transmitted culture. Recent studies have indicated that the family is indeed the chief agent which preserves values and culture and transmits them to the new generations. The millet system favoured the fusion of the family and the community - the latter can be regarded as an overgrown family (italics added) - and thus provided a sound basis for the preservation of the grass-roots ethnic identity and custom of a given group". ${ }^{15}$

The millet system in the Ottoman Empire went through transformations according to the changes in the social and political processes in the Ottoman society. One of these transformations in the millet system, which was very important for Ottoman Macedonia, was the division in frame of the Rum millet. The Bulgarian Exarchate was created in 1870 and was sanctioned by the Sultan. With its creation emerged a division of the Orthodox Christians within the Ottoman Balkan. The Orthodox subject that belonged to the Constantinople Patriarchy in a confessional context was until then "Rum". A choice was given with the creation of the Exarchate. ${ }^{16}$ The opportunity people had about deciding or choosing between the Greek Orthodox Patriarchy, the Bulgarian Exarchate or the Serbian Orthodox branch of the Patriarchy ${ }^{17}$, and their respective schools, was not a decision in an ethnic or national identity context. For the Macedonian Orthodox population this was the only option in order to have a regular practice of faith, as well as the only option for acquiring any kind of education in their homeland. The Porte and these church institutions cared neither about the authenticity of the native, vernacular culture of this population, nor about its linguistic distinctiveness. Therefore, these institutions began to implement their language patterns, which were codified and developed in their independent states - neighbours to the Ottoman Macedonia. The first language used in schools was the Greek language (totally different from the Macedonian Slavic language), followed by the Bulgarian and Serbian

${ }^{15}$ K. H. Karpat, Millets and Nationality: The Roots of the Incongruity of Nation and State in the PostOttoman Era, in: Christians and Jews in the Ottoman Empire, p. 141-143.

16 The Exarchate and Patriarchy viciously fought to gather more believers on each side and in every possible way. This only further deepened the corruption of the local Ottoman administration. With the formation and reinforcement of the national states (Greek, Serbian and Bulgarian) their church institutions became important part of the national administration of these neighbouring Balkan states of Ottoman Macedonia.

17 The Serbian Orthodox Church in the Principality of Serbia gained its autonomy in 1831, and was organized as the Metropolitanate of Belgrade, remaining (until 1879) under the supreme ecclesiastical jurisdiction of the Ecumenical Patriarchate of Constantinople. Thus it gained jurisdiction solely over the population living in the Serbian state. The Serbian church did not acquire a distinct Serbian millet in the Ottoman Macedonia, therefore the work of the Serbian clerical and educational propaganda had numerous obstacles. Its space for manoeuvre was limited, and functioned between satisfying the Ottoman authorities in Macedonia, and through a complex dependency on the Constantinople Patriarchate. This partial solution to the Serbian clerical-educational issue under the protection of the Greek Constantinople Patriarchate could not satisfy the Serbian government. The main argument of the Serbian diplomacy was the Ottoman "Law for public education". With the provisions of this law the Serbian politicians succeeded in overruling the Constantinople Patriarchate's primacy in some parts of Ottoman Macedonia up to a certain point. 
languages, which, although related South Slavic languages, were not identical with the Macedonian vernacular. Since the schools were under the protectorate of the churches, their influence on the socialization processes in the Ottoman society was considerable. ${ }^{18}$ On one hand, the doctrine of the Greek state was that this population should either return to the Patriarchy, or stay under its jurisdiction as so-called "Greeks" who "have forgotten their Greek language and origin." 19 On the other hand, the similarity between the Bulgarian and Serbian language (as South-Slavic languages) allowed the development of a doctrine, according to which the Macedonian mother tongue was only the so-called "dialect" of the Bulgarian or Serbian language. Consequently, the Ottoman administration and Macedonia's Balkan neighbours proclaimed that the Slavic Orthodox Christians in Macedonia are only Greeks, Bulgarians and Serbs. ${ }^{20}$ This was based on the use of language in schools/churches (patriarchal and exarchal), which was an opportunity and obligation given by the millet system. However, it was not based on the fact of the use of the Macedonian mother tongue at homes and inside the family corpus. Based on the identification of the core elements of the "mixed" population (in a certain fabricated middle-aged "national" context), the neighbouring Balkan states began to claim their right to her territory and to recognize their own "national representatives" in the exarchal or patriarchal millets. ${ }^{21}$ By this, the equation "millet=nation" in Ottoman Macedonia evolved into "church/school=nation". The one who had a right to create a church or school, assumed to have the right to label his disciples as his own "national" members.

This generated a great discrepancy between the family as the millet's basic nucleus, where the vernacular mother tongue and culture continued to be nurtured and maintained (especially due to the fact that an extremely small percentage of women were part of the educational process, and because a large percentage of the population was illiterate), and the millet, i.e. the overgrown family where an individual would be exposed to all these external influences. The indigenous resistance of the majority of the population in Ottoman Macedonia (the Macedonian Slavic Orthodox population) against this imposed discrepancy between the family and the community was the basic social precondition for the Macedonian so-called Revival processes of the late 50ties and 60ties of the $19^{\text {th }}$ (Phase A according to theory of Miroslav Hroch) ${ }^{22}$

${ }^{18}$ Catholic and Protestant Missions had only a very limited influence in Ottoman Macedonia. The emerging of Uniates and Protestant communities in the Ottoman Macedonia is also very interesting to research, but it is not the focus of this article.

19 Д. Вамваковски Љоровски, Како не́ нарекуваше Гриија, Политичката реалност и изумирањето на митот за Давид и Голијат: Македонија и Гриија на Балканот, Скопје: 2014, p. 30-37.

${ }^{20}$ S. Kiselinovski, Nacionalna struktura stanovništva Makedonije 1900-1913, „Časopis za suvremenu povijest" 1979 , vol. 11, no 1, p. 67-79.

${ }^{21}$ These divisions of the Slavic Orthodox Christians represent the basic ingredients of the so-called "Macedonian salad", because the diversity of the Muslim population and the Vlach, Jewish, and Roma enclaves are characteristics of the entire Ottoman Balkan, and not only of Ottoman Macedonia.

${ }^{22}$ М. Пандевска, Транзициите во македонското национално-ослободително движење: низ теоријата на Мирослав Хрох, in: Транзициите во историјата и културата, Скопје 2008, p. 175. 
The Ottoman Empire failed to perceive the process of disintegration of the Orthodox Church and its ecumenicity as well as its transformation into foreign organisations. These national organisations would concentrate much more on the political struggle on behalf of their state, than on satisfying the religious and educational needs of the Orthodox population in Ottoman Macedonia. ${ }^{23}$

\section{THE ALTERATION OF THE TERM MILLET AND ITS ORIGIN: THE $19^{\mathrm{TH}}$ CENTURY TURKISH DICTIONARIES}

Renouncing the ambition of analysing all of the existing Turkish dictionaries (from the $19^{\text {th }}$ and the beginning of the $20^{\text {th }}$ century) that interpret the word millet, we begin the analysis with an interesting French-Turkish Dictionary by Thomas Xavier Bianchi $(1783-1864)^{24}$, published by the Geographical Association in $1831 .{ }^{25}$ This dictionary is of interest to us for several reasons. Firstly, the same French-Turkish Dictionary was published again in Paris in 1846, but this time the publisher was London's Oriental Translation Committee. ${ }^{26}$ This indicates that its use also spread among the English intellectual and political elite. The second interesting aspect is the feature that these publications have, which is the instruction stating their target group. The original title of this dictionary states that it is meant for: "translators, merchants, sailors and all the travellers who stay in the Levant", and in the instruction of the second edition in the first place we find: "diplomatic agents and consular officers, translators, merchants, sailors and all the travellers who stay in the Levant." Why do we point out these particularities? Because the understanding of the social relations and the situation of the "Levant" (and more specifically in our case of Ottoman Macedonia) that comes from this dictionary is intended precisely for the senior public servants that regularly report to their governments and thus directly participate in the creation of the policies of their states. For these reasons we will briefly look into the profile of the author of this publication - T.X. Bianchi. The first pages of the dictionary reveal that he belonged to the Western political and intellectual elite. He was a Chevalier (Officer) of the French Legion of Honour, Secretary-Interpreter for oriental languages, member of the Central Commission of the Geographic Association, member of the Asiatic Society in Paris and correspondent to the London branch office. In the second edition it is stated that he became member of the Royal Asiatic Society in London. The later editions provide the information that he was decorated with the Sultan's Order of Nichani-Iftikhar. His

\footnotetext{
${ }^{23}$ M. Pandevska, The Term Macedonian(s) in Ottoman Macedonia: On the Map and in the Mind, „Nationalities Papers. The Journal of Nationalism and Ethnicity” 2012, vol. 40, no 5, p.757.

24 Dictionnaire des orientalistes de langue française, eds. F. Pouillon, Paris 2008, p. 113.

25 T.X. Bianchi, Vocabularie Français-Turc, A L'usage des interprètes, des commerçans, des navigateurs, et utres voyageurs dans le Levant, Paris 1831, p. 508.

${ }^{26}$ T.X. Bianchi, Dictionnaire Français-Turc, A L'usage des interprètes, des commerçans, des navigateurs et utres voyageurs dans le Levant, Paris 1846, p. 470.
} 
biography describes the ten years he spent in Istanbul where he worked as an advisor to the French consuls. The dictionary was used as sort of French-Turkish conversation guide and among other things contained specific trade and religious terms, names of civil and military officials in the Ottoman Empire, as well as certain names of countries, cities, mountains, and other geographic sites in the "Levant". Taking this information into consideration the dictionary became a propaganda tool for the French language and its influence on the Ottoman Empire's culture. From the abovementioned, it can be concluded that Bianchi was a renowned orientalist with an indisputable competency and political influence.

The two initial editions of his dictionary gave the words first in French; afterwards followed the Turkish explanations. For example, the term millet is presented as direct explanation of the French word nation. ${ }^{27}$ Next followed the other definitions: "qavm" (people), "ümmet" (religious community, coreligionist); "-chretienne" (-Christian); "franciz miletti" (French millets), "milleti osmaniiie”" (Ottoman millets). Therefore, one could conclude that whenever a French speaking diplomat, merchant, traveller or writer, would come across the word millet he/she would literally link it to the word nation, i.e. specifically as identical to the understanding of the French nation - "franciz miletti". Thus, in the term millet, the diplomats stationed in Ottoman Macedonia, recognised "formed nations" (in the French context of the understanding of the word at the time - Christian nation???). Curiously, in the reverse Turkish-French Dictionary the same author gives a somewhat wider definition of the term. He first writes the word millet written in Arabic and then millet (in its Latin transcription) followed by the explanations of its meaning in French: "1) Loi" (law) and "religion", "2) Nation", "people", "considere sous le rapport religieuh" (religious affiliation) and "La religion ou nation chrètienne" (the religion of the Christian nation). ${ }^{28}$

The principle of linking the term millet to the notion of nation can also be found in the Dictionnaire turc-arabe-persan [Türkisch-arabisch-persisches Handwörterbuch] by Dr Julius Theodor Zenker (1811-1884) ${ }^{29}$ published in Leipzig in 1866 (the meanings of words are given in French and German). ${ }^{30}$ Zenker was also a renowned orientalist, Doctor of Philosophy, and member of the Orientalist Association in Leipzig and Halle. His books are part of the Oriental Library, in which one can find the term millet with explanations in the following order: "loi" (law), "religion", "communion religious" (religious community), "sect", "people", and "nation".

\footnotetext{
${ }^{27}$ Bianchi, Vocabularie Français-Turc..., Paris 1831, p. 508; Bianchi, Vocabularie Français-Turc..., Paris 1846, p. 470.

${ }^{28}$ T.X.Bianchi et J.D. Kieffer, Dictionnaire Turc-Français, A L'usage des interprètes, des commerçans, des navigateurs et utres voyageurs dans le Levant, Paris 1850), vol. 2, p. 997.

${ }^{29} \mathrm{http} / /$ www.turquie-culture.fr/pages/turc-et-langues-turques/biographies-de-linguistes/zenker-ju les-theodore-1811-1884.html [access: 27.06.2012].

${ }^{30}$ T.J. Zenker, Dictionnaire turc-arabe-persan [Türkisch-arabisch-persisches Handwörterbuch.], Leipzig 1866, p. 876.
} 
In the Turkish and English Lexicon by Sir James W. Redhouse (1811-1892) ${ }^{31}$, published in Constantinople (Istanbul) in 1890, the first meaning of the word millet is explained with the phrase "one's belief", followed by "faith", and "religion". The second meaning is given as "a nationality" with an additional explanation: "especially people united by common faith". The last explanation is "sect". ${ }^{32}$ Like the previous authors, Redhouse is an orientalist; a man who spent many years living in the Mediterranean region, in Smyrna and Istanbul. He published his first Turkish-English Dictionary in 1830. In the year 1838 he returned to the Ottoman capital where he worked as an interpreter for the Grand Vizier and the Ministry of Foreign Affairs of the Sublime Porte. His biography also shows prolific diplomatic activity for which he was decorated with the Sultan's Order of Nishani Iftikhar and the Persian Order of the Lion and the Sun. During the 1850s he became senior officer in the British Foreign Office and a member of the Royal Asiatic Society. Thus, apart from being a scholar philologist, he is also a representative of the political elite of the Occident. These examples justify Edward Said's statement according to which 'by the middle of the $19^{\text {th }}$ century the Orient had become, as Disraeli said, a career, one in which one could remake and restore not only the Orient but also oneself ${ }^{33}$ From the presented examples of these dictionaries one can clearly conclude that the understanding of the word nation is already placed in direct correlation with the word millet, if not in its first, then in the remaining explanations of the term.

In our research we also analyze the Ottoman dictionaries/glossaries from the last decades of the $19^{\text {th }}$ century. Hence, in Naçi's semi-etymological glossary (published in Istanbul in 1891) under the word millet we are offered precisely the following explanation "faith and shariat" (religious law). The comment "according to us, faith and millet are one and the same" is given as an additional explanation. Further on, Naçi continues with "a group that belongs to the same faith; Islam millet." What captured our attention is the fact that the author in the explanation gives a strong suggestion that the word millet: "should not be used as a replacement for the word nation, which means community (group) of people born in one country and living under the same government. And as a replacement one should use the words: kavm (people) ümmet (religious community, coreligionists)." 34

Şemseddin Sami (Samy Bey Frachery) is also known for his lexicographical works. In 1882 he published Françis-Turc Dictionnaire (Kamûs-ı Fransevî) - an edition which we could not find. However, we did acquire the second, edited and complemented edition of this Françis-Turc Dictionnaire by Frachery, published in 1896. In it for the French term nation, Frachery wrote: "Numerous community, people, ge-

31 G. Niki, The Making of a Legend-Redhouse, „The Turkish Daily News”, 25.10.2002, http://www. learningpracticalturkish.com/redhouse-dictionary-history.html [access: 18 October 2017].

32 W.J. Redhouse, A Turkish and English Lexicon, Constantinople 1890, p.1965.

33 E.W. Said, Orientalism, New York 2003, p. 166.

34 Ö. Naçi, Lügat-l Sözlük, Istanbul 1891, p. 831. 
nus, a group which speaks one language and which is connected by the same ethical/ moral values/norms and traditions". In continuation he states that: "It is wrong to use the word millet in its place (i.e. as a synonym for the term nation)..."35

From an Ottoman point of view this is quite logical because the millet system of the empire was not devised to only connect religious groups which spoke the same language, and also had the same ethical/moral values/norms and traditions. On the contrary, in the Ottoman Empire, the millet had a broader meaning as a denomination for a religious community which may have had different norms/traditions or ethnic backgrounds. The recognition of the "otherness" in the empire derived from the existence/acceptance of the use of a different Holy book for one, or another religious community, which was a practice far removed from what would have been the case if the millets were created on an ethnic or national basis. ${ }^{36}$

In 1883 Samy Bey Frachery also publishes a Turc-Françis Dictionnaire. In the Introduction he states his motive behind this dictionary: "There are dictionaries which state that contain vocabulary from a Turkish-French provenance, but in fact the words which they include do not reflect the Turkish language at all. For example, the two huge volumes of Bianchi's Turkish-French dictionaries are on the one hand too limited to be a total representation of the Turkish language, and on the other hand, the words included in them are almost foreign to the Turkish language. His intention was to take the fusion of Arabic, Persian and Turkish as one language form. In addition, while making the dictionary in relation to the Turkish language, only several words were gathered from the three before mentioned languages, which were later scattered in one big mess. These dictionaries are not good for any of the three languages". He continues his Introduction by explaining a problem with the foreign dictionaries of the Turkish language: "The Turkish language does in fact contain a large number of Arabic and Persian terms, but even though the French language contains a large number of Greek terms, there has not been an attempt to create one dictionary of the Greek and French languages intertwined. Firstly, one cannot pick out a handful of terms from the vast Arabic and Persian dictionaries, which are also present in the Turkish language without avoiding the risk of looking ridiculous and unintelligible. Secondly the Arabic and Persian terms which infiltrated the Turkish language did not always attain the same meaning they had in their language of origin. That is why there is a need for one dictionary to contain all of the words which make the Turkish language, and to have their meaning explained solely through the prism of the Turkish language". ${ }^{37}$ In the Turc-Françis Dictionnaire from 1883, Şemseddin Sami lists the words firstly in their Ottoman form, after which he gives the Latin transcription of the word-in our case the word millet - which is followed by the explanation of the term in

\footnotetext{
${ }^{35}$ Ş. Sami, Kamûs-ı Fransevî, Fransizca'dan Türkçe'ye Lügat, Istanbul 1896, p. 665-666.

${ }^{36}$ B. Lewis, The Political Language..., p. 58.

37 Ş. Sami, Kamûs-ı Fransevî, Türkçe'den Fransizca'ya Lügat, Istanbul 1883, p. v-vi.
} 
French: "Religion; Doctrine religieuse. Communautè religieuse. Nation - but instead of it, ümmet (religious community, coreligionists) should be used". 38

Şemseddin Sami's famous glossary Kamûs -i Türki, published in Istanbul in 1899/1900, complements his aforementioned statements. Two explanations are given for the word millet:

1) faith, religion, additionally explained as faith and millet, the two are the same,

2) a community that belongs to a single faith or religion..$^{39}$ The examples so far given are emblematic and thus we conclude that the term nation, in glossaries of the Ottoman linguists cannot be found in use as a synonym for the word millet and in some cases it is strictly requested not to be used as a synonym of the term millet. In order to obtain a more a comprehensive view of how these Ottoman scholars grasped the Western term nation, we looked through their short biographies.

Omar Naçi (1850-1893), known as the Teacher, was the representative of the intellectual elite of the Ottoman Empire at the time of Tanzimat. ${ }^{40} \mathrm{He}$ was a well-known poet and linguist, as well as a newspaper and magazine editor. In his biography one can see that he also graduated from the madrasah, thus acquiring religious education. He spent most of his youth living with his uncle in Varna. Afterwards he travelled throughout his vast fatherland. As an Ottoman poet and writer, Naçi also played a role in the grammatical modernisation of the Turkish language. He was also familiar with the works of Emile Zola, Victor Hugo and other Western novelists. From these brief biographical references one could easily conclude that Omar Naçi was an intellectual of his time, educated and talented, familiar with the Western societies and culture, having experience of living in the Balkan areas of the Ottoman Empire that were touched by various European cultures and religions. In his rich and innovative dictionary, the terms millet and nation are not only disparate, but also Naçi insists not to regard them as identical.

The second intellectual-researcher from the Modernisation time, who also had some Western education, is Şemseddin Sami $(1850-1904) .{ }^{41}$ He is a writer, a linguist and a philosopher. He comes from the famous Albanian dynasty Frasheri, and apart from knowing the European languages, he had excellent governance of the Turkish, Greek and Albanian language. Şemseddin Sami (Sami Bey Frasheri) is also the author of the Encyclopaedia of General Science Kamûs-ül Â'lâm (6 volumes, 1889-1898), which is still popular and respected in Turkey. "Just as he wrote the first Turkish nov$\mathrm{el}$, he also wrote one of the first Albanian theatrical plays... He is the author of the

\footnotetext{
${ }^{38}$ Ibidem, p. 1074.

39 Ş. Sami, Kamus -i Türki, Istanbul 1317 [1899/1900], p. 1400. Şemsudin Sami used some letters by adapting Arabic letters to the Turkish phonetics, thus introducing a new form into the orthography.

$40 \mathrm{http}: / /$ www.edebice.net/index.php?option=com_content\&view=article\&id=132:muallim-naci1850-1893\&catid=31:tanzimat-edebiyat\&Itemid $=122$ [access: 27.06 .2012$]$.

${ }^{41}$ The Forgotten Minorities of Eastern Europe: The History and Today of Selected Ethnic Groups in Five Countries, eds. A. Tanner, Helsinki 2004, p. 213.
} 
Albanian alphabet, which is founded on today's Latin alphabet (1886) and in 1900 he also published a grammar of the Albanian language. By writing in Turkish with the Arabic letters in a reformed way, adapted to the Turkish phonetics he has a special place in the history of the Turkish literature and language". ${ }^{42}$ As quoted before, this "renaissance man" also does not link the terms millet and nation.

Based on the analysis of the quoted dictionaries/glossaries and the profiles of their authors, Western orientalists and Ottoman linguists, one can see the discrepancy in the familiarity and the recognition of the social processes between the Orient and the Occident. While the Ottoman intellectuals, whose social reality was the millet system, show some understanding of the Western European concept of nation and make the necessary distinction between these two concepts, the Western orientalists in a quite inadequate manner mirror or project their social reality onto the Ottoman Empire. ${ }^{43}$ With regard to these interaction processes, Edward Said comments: "Such ideas and their authors emerge out of complex historical and cultural circumstances, at least two of which have much in common with the history of Orientalism in the nineteenth century. One of them is the culturally sanctioned habit of deploying large generalizations by which reality is divided into various collectives: languages, races, types, colours, mentalities, each category being not so much a neutral designation as an evaluative interpretation (italics added). Underlying these categories is the rigidly binomial opposition of «ours» and «theirs», with the former always encroaching upon the latter (even to the point of making «theirs» exclusively a function of «ours») ... What is required of the Oriental expert is no longer simply «understanding»: now the Orient must be made to perform, its power must be enlisted on the side of «our» values, civilization, interests, goals. Knowledge of the Orient is directly translated into activity, and the results give rise to new currents of thought and action in the Orient". 44

If one agrees with Said's paradigm that Orientalism is a distribution of geopolitical consciousness, then the philological reconstruction of the equation "millet=nation" demonstrates that the term millet obtains its oriental validity, only after receiving its new Western meaning. This process of misinterpretation slowly but surely led to a change in the Eastern perception of this term. A power imbalance heavily favouring the West, created a dialectical process, i.e. Orientalism, by which the peoples of "the Orient" began to define themselves and "others" with Western terminology and denotations. Thus in today's Turkey the word millet defines the term nation. The Western models were also being used together with the Western terms: "After a good century of constant intervention in (and study of) the Orient, the West's role in an East it-

\footnotetext{
42 И. Ортајли, Најдолгиот век на Империјата, Скопје 2009, p. 256-257.

${ }^{43}$ The analysis discovers that the Western orientalists did not have an equivalent understanding of the term nation yet. However, this is a completely different issue that also deserves special attention. If in a focus of the interpretations, the basic source material once again used was dictionaries, one would doubtless discover particularities in the individual and often vague understanding of the terms religion, nation, nationality, people, race, etc.

${ }^{44}$ E. Said, Orientalism, p. 227-238.
} 
self responding to the crises of modernity seemed considerably more delicate. There was the issue of outright occupation; there was the issue of the mandated territories; there was the issue of European competition in the Orient; there was the issue of dealing with native elites, native popular movements, and native demands for self-government and independence; there was the issue of civilizational contacts between Orient and Occident". ${ }^{45}$

Ottoman Macedonia, being geopolitically positioned in the center of the Balkan Peninsula and having a complex political situation, could not stay out of these processes. Macedonia shifted from a central Ottoman province to a peripheral one in the last decades of the $19^{\text {th }}$ century, more precisely after the developments related to the Great Eastern Crisis (1875-1881). ${ }^{46}$ By that time, the national Balkan states were created; they were directly interested in the remaining Ottoman Balkan territories, and each one of them found a protector in one of the great European geostrategic players.

\section{THE $20^{\mathrm{TH}}$ CENTURY TURKISH DICTIONARIES: THE EVALUATIVE INTERPRETATION}

In our research we examined the dictionaries in the first decades of the $20^{\text {th }}$ century and we noticed that the influence of the already performed evaluative interpretation by Western orientalists could be found in the dictionaries from various proveniences. For instance, the Turkish-Arabic-German Dictionary, written by Tewfik Ahsan and E.A. Radspieler (published in Vienna and Leipzig), has the following explanations for the term millet: "Nation", "Volk" (people) and "Religion". ${ }^{47}$ A similar example is the Turkish-French Dictionary by Darian Kelekian, published in Constantinople in 1911 dedicated to the memory of the work of Sami Bey Frasheri. Even so, the author does not follow Frasheri's instruction and for millet writes "Nation", followed by "Religious community". In the excellent and still relevant dictionary by Šukrija Alagić, Professor of the Great Sarajevo High School that was published in 1913, the word millet has the following meanings: "faith, religion, members of a religion, people"; at the end the word "nation" is noted. ${ }^{48}$ Although there are probably some exceptions to this rule, in our research we came across only one from this period, i.e. the Dictionary of the Persian Language by E.H. Palmer, Professor of Arabic Language at

\footnotetext{
45 Ibidem, p. 248.

46 М. Пандевска, Периодизация великого восточного кризиса 1875-1881, in: Балканот и Русија: Опитото и специфичното во историскиот и културниот развиток, Скопје 2010, p. 23-34.

${ }^{47}$ T. Ahsan und E.A.Radspieler, Türkisch-Arabisch-Deutsches Wörterbuch, Wien-Leipzig 1910, p. 166.

48 Š. Alagić, Arapsko-Srpsko-Hrvatski Rječnik za izbor iz Kitabu Sireti Resulillahi, Zemaljska Vlada za Bosnu i Hercegovinu, 1913, p. 171.
} 
Cambridge University. ${ }^{49}$ In this dictionary, the term millet has only the explanations: religion and faith.

By the second half of the $20^{\text {th }}$ century three variations of interpretation of the term millet appeared in various Turkish dictionaries. In some dictionaries the term millet is explained not only with the terms "religion" and "faith", but also with the term "nation". ${ }^{50}$ And there are dictionaries that for the term millet use the term "people". ${ }^{51}$ On the other hand, there are dictionaries in which millet is synonymous to only one word - a "nation". ${ }^{52}$ During the research we came across one Balkan etymological dictionary from the 1970s that does not use the term "nation" as equivalent to the term millet. That is Petar Skok's dictionary published in $1972 .{ }^{53}$ The OttomanTurkish Dictionary by Ferit Develioglu published in Ankara in 1984 is also very exact. It states that millet means: "1) din, mezhep" (faith, religion), "2) bir dinde veyā mezhepte bulunanlarin topu" (community that belongs to a certain faith - religion), "3) sinif, topluluk" (community, class), "4) makule, kategori (category)". The interventions and the changes in the understanding of the terminology are also evident from the explanations in the etymological Ottoman-Turkish Dictionary published in 1965 by Mustafa Nihat Özön. ${ }^{54} \mathrm{He}$ started his list of synonyms of the term millet with its original meaning "faith, sect" and "a group that belongs to a certain faith or sect"; however, in the third listing he added the term "people, nation" immediately followed by a remark " $20^{\text {th }}$ century". Hence, he located its altered meaning and interpretation in the $20^{\text {th }}$ century.

Towards the end of the last century and the beginning of the new millennium the term millet is more often defined as nation, rather than as faith or religion. Our research from the available online dictionaries has discovered that the terms faith and

49 E.H. Palmer, Concise Dictionary of the Persian Language eleventh impression, London 1931, p. 599.

${ }^{50}$ H. Wehr, Arabisches Wörterbuch, für die Schriftsprache der Gegenwart, Veb Otto Harraassowitz, Leipzig 1956, p. 818; Х.К. Баранов, Арабско-Русский Словаръ, Moskva 1958, p. 973; J. Dayre, M. Deanovic and R. Maixner, Hrvatskosrpsko-francuski rečnik, Zagreb 1960, p. 229; T. Muftic, ArapskoSrpskohrvatski, Sarajevo 1973, p. 3354; М.Н. Османова, Д.Х. Дорри, Л.Н. Киселева et al., ПерсидскоРусский Словаръ, Москва 1983, p. 554; В.Г. Георгиев, Р. Бернар, И.Н. Иванов. et al., Български етимологичен речник, София 1986, p. 793-794; S. Abdulah, Turcizmi u srpskohrvatskom jeziku, Sarajevo 1989, p. 463.

51 Речник на македонскиот јазик со српскохрватски толкувања, eds. Б. Конески, Скопје 1961; Македонско-Русский словаръ, eds. Н.И. Толстого, Москва, 1963, p. 258; М.A. Ağakay, Turkce Sözlük, Ankara 1966, p. 520.

52 Н. Ванчев, Г. Гълъбов, Г. Класов. et al., Турско-български речник, София 1952, p. 363; Х.Г. Кор Оглы, Персидско-Русский и Руско-Персидский Словаръ, Москва 1957, p. 171; А.Н. Баскалов, П. Голубова, А.А. Камилева et al., Türcç - Rusça Sözlük, Москва 1977 - Истанбул 1989, p. 629.

53 P. Skok, Etimologijski Rječik Hrvatskog ili Srpskog Jezika, Zagreb 1972, 2 , p. 424. F. Develioğlu, Osmanica-Türkçe Ansiklopedic Lügat, Ankara 1984, p. 775.

54 “Millet, 1) Din, mezhep 2) Bir din veya mezhepte bulunar grupu. 3) Millet, ulus (XX.yy)... " in N. M. Özön, Büyük, Osmanlica-Türkçe Sözlük, Istanbul 1965, p. 474. 
religion are no longer synonyms of the term millet. ${ }^{55}$ Hence, the Orientalist misinterpretation of the $19^{\text {th }}$ century led to the complete alteration of the term millet.

\section{CONCLUSION}

All these examples illustrate what the philosopher Quentin Skinner called a mythology of parochialism: "This danger must arise, of course, in any kind of attempt to understand an alien culture of an unfamiliar conceptual scheme. If there is to be any prospect that the observer will successfully communicate his understanding within his own culture, it is obviously dangerous, but it is equally inescapable, that he should apply his own familiar criteria of classification and discrimination". ${ }^{66}$ In such way, the processes are easily taken out of the historical time context, and as in our case, outside of the context of the historical space. It is evident that the notion nation for the territory of the Ottoman Empire cannot be equated with the term millet in the $19^{\text {th }}$ and early $20^{\text {th }}$ century. The misinterpretation became alteration, and this alteration of the term rapidly moved towards the present.

We could agree that modernisation and globalisation played their role in these adjustments, and not only of this notion, but also of many other changes. However, from a historical aspect, and from the viewpoint of other related social sciences, these issues should be approached with more caution. When the scholars study the social phenomena of the $19^{\text {th }}$ century, they should be more careful in avoiding a projection of the modernisation of their own time and space, onto others. ${ }^{57}$ This especially applies

\footnotetext{
55 _“millet-nation [la]; peuple [le]”. M. Yildiz, Turkish-French Dictionary, http://translation.babylon. com/turkish/to-french/millet/ [access: 27.06.2012];

-“millet-nation, people, folk". Babylon Turkish-English Dictionary, http://translation.babylon.com/ turkish/millet/[access: 27.06.2012];

-“millet-nation [die], Volk [das]”. M. Yildiz, Turkish-German Dictionary, http://translation.babylon. com/turkish/millet/[access: 27.06.2012];

-“millet-nation". German-Turkish Dictionary. LingvoSoft free online German dictionary, http://www. lingvozone.com/main.jsp?action=translation\&do=dictionary\&language_id... [access: 27.06.2012];

-“millet-nation". English-Turkish online Dictionary-a Bilingual Dictionary from ESTACO, http://online.ectaco.co.uk/main.jsp;jsessionid=bc302c40d4a81315f581?do=e-services- [access: 27.06.2012];

-"millet- the collectivity; millet-commonwealth; millet-folk; millet-nation; millet-nationality; milletpeople". Zargan Turkish Glossary, http://www.zargan.com/sozluk.asp?Sozcuk=millet\&DisplayLang=2 [access: 27.06.2012];

-"millet-nation; millet-people; millet-everybody; millet-folk; millet-folks; millet-they". Langtolang. comDictionary, http://www.langtolang.com/?selectMenuLang=1\&txtLang=millet\&selectFrom-Englis [access: 27.06.2012];

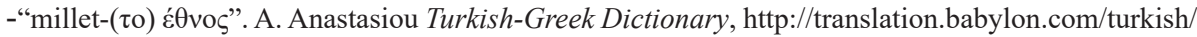
millet/ [access: 27.06.2012].

${ }^{56}$ S. Quentin, Meaning and Context: Skinner Quentin and his critics, Cambridge 1988, p. 45.

${ }^{57}$ Bernard, The Political Language, p. 58.
} 
to the understanding of nation and the level of national awareness seen from a present day perspective, which is presented as the basic "measuring instrument" that establishes the level of "national awareness" in the $19^{\text {th }}$ century. For this reason, the use of the terms nation and nationality in the Ottoman context, as well as their identification with the "completed national belonging" in the empire, and therefore in the Ottoman Macedonia in that century, should also be approached with more caution. ${ }^{58}$

The historical distance we have today has led us to a conclusion that the literal equality "millet=nation" is not correct. If this equation was valid the Muslim millet should have been transformed into a single nation. The Turkish, Bosnian and Albanian nations were created on the Balkan Peninsula, although they have not always had the Muslim religion as a common trait (such example are the Albanians). If this equality had its social reality, then it is difficult to explain how separate nations were created where there has been no special millet formed (on the Balkan such example are the Romanian, Serbian, Montenegrin and Macedonian nations, however many other examples exist when analyzing the whole territory of the empire). Questions arise even if we look at the Vlach ethnic group on the Balkan. If the equation is correct, then the question arises: Why a separated Vlach nation has not been created, especially in the light of the fact that in the year 1905 the Sultan recognized these particular subjects living in Ottoman Albania, Ottoman Macedonia and Ottoman Thrace as a separate Vlach (Ulllah) millet?

The (mis)use of the equation "millet=nation" is most obvious when analyzing the situation of Ottoman Macedonia in the period of the $19^{\text {th }}$ century and the first decades of the $20^{\text {th }}$ century, when the surrounding states had territorial aspirations. They went even further by simplifying the equation to "millet=school /church=nation". In such a manner, everyone in Ottoman Macedonia who attended a certain school and was part of a particular church was considered a member of "their" nation. The question whether the educational process successfully imposed a national consciousness (or erased the consciousness of "otherness") on some of the Macedonian population, is a completely separate issue. Automatically equating an "educational process" with the establishment of a "national consciousness" is a dogmatic formula that cannot survive serious scrutiny. This formula is not used when establishing the national development processes in many other nations in Europe that also had foreign educational institutions or foreign languages, which were instrumental in the so called Revival and liberation processes. ${ }^{59}$ That is why the use of the exogenous labeling or self-naming of the Macedonians as Serbs, Bulgarians or Greeks should be used with caution in contemporary historiography. These exogenous labels or self-naming can be used as an affir-

${ }^{58}$ We do not wish to diminish the importance of the millet system with this statement, since the millet system quickened the process of forming a nation for some of the Balkan peoples. In most cases those were peoples which were located on the borders of the Ottoman Empire for a longer period of time, which made them more strongly exposed to the European influence of the Enlightenment.

${ }^{59}$ N. Jordanovski, Some Considerations about the $19^{\text {th }}$ century National Revival in Macedonia, in: Miejsce Macedonii na Balkanach, Historia-Polityka-Kultura-Nauka, Kraków 2005, p. 199-208. 
mation of national consciousness's only in the cases where the individuals left clear, unambiguous, records of their feelings of belonging to these (or others) national collectivities (especially in the cases where the individuals left precise data of belonging to a certain territory as their homeland). In the historical sources where there existed exogenous labeling or self-naming (as Bulgarians, Greeks or Serbians), much of the evidence shows that this represented the millet/church affiliation, and not some sort of "national self-determination". A particularity of Ottoman Macedonia was the church division of the Macedonian Slavic Orthodoxy, and not some kind of Macedonian - exclusive ethnic or national mixture of the population. ${ }^{60}$

The social sciences cannot be satisfied simply by noting the changes in the linguistic features of a language, because their influence is not insignificant. The inadequate identification of the term millet with the term nation strongly stimulated irredentism among the small Balkan independent states - neighbours of Ottoman Macedonia. In other words, the substitution of the term nation for millet in the $19^{\text {th }}$ century and the beginning of the $20^{\text {th }}$ century was used as justification for their respective expansionistic policies and the "holy" right to look for, find, count, recount, and convert their "national compatriots" in Ottoman Macedonia. All three countries opened schools in order to propagate their national ideals; they formed churches loyal to their bishops, made maps and ethnographies to justify their demands, and when the more peaceful methods did not guarantee success (mostly because of the emergence and the activities of the indigenous underground Macedonian revolutionary organisation 18931908) they financed paramilitary groups in order to recruit supporters for their cause among the Macedonian population. ${ }^{61}$

This substitution of nation for millet led to relentless struggles for imposing church administrative boundaries in Ottoman Macedonia. These church administrative boundaries were "translated" as "national" borders. Later, at a critical moment, the church struggle led to the Balkan Wars (1912-1913) and the division of Ottoman Macedonia into three parts. The wars were followed by the unavoidable ethnic cleansings, exoduses, assimilations, and occupation regimes.

\section{SUMMARY}

The research and the comparative analyses of the Turkish dictionaries/glossaries demonstrated that the notion nation for the territory of the Ottoman Empire cannot be equated with the term millet in the $19^{\text {th }}$ and early $20^{\text {th }}$ century. The misinterpretation became alteration, and this alteration of the term rapidly moved towards the present.

\footnotetext{
${ }^{60}$ M. Pandevska, The Term Macedonian(s) in Ottoman Macedonia: On the Map and in the Mind, „Nationalities Papers. The Journal of Nationalism and Ethnicity” 2012, vol. 40, no 5, p. 759-761.

${ }^{61}$ M. Mitrova, The Treaty of Bucharest and the Unresolved Balkan Issues, „Macedonian Historical Review" 2011, no 2, p. 235-254.
} 
Therefore, when the scholars study the social phenomena of the $19^{\text {th }}$ century, they should be more careful in avoiding a projection of the modernisation of their own time and space, onto others. This especially applies to the understanding of nation and the level of national awareness seen from a present day perspective, which is presented as the basic 'measuring instrument' that establishes the level of 'national awareness' in the $19^{\text {th }}$ century. For this reason, the use of the terms nation and nationality in the Ottoman context, as well as their identification with the 'completed national belonging' in the empire, and therefore in the Ottoman Macedonia in that century, should also be approached with more caution. The historical distance we have today has led us to a conclusion that the literal equality 'millet=nation' is not correct. For example, if this equation was valid the Muslim millet should have been transformed into a single nation today.

The (mis)use of the equation 'millet=nation' is most obvious when analyzing the situation of Ottoman Macedonia in the period of the $19^{\text {th }}$ century and the first decades of the $20^{\text {th }}$ century, when the surrounding states had territorial aspirations. They went even further by simplifying the equation to 'millet=school/church=nation'. In such a manner, everyone in Ottoman Macedonia who attended a certain school and was part of particular church was considered a member of 'their' nation. The question whether the educational process successfully imposed a national consciousness (or erased the consciousness of 'otherness') on some of the Macedonian population, is a completely separate issue. Automatically equating an 'educational process' with the establishment of a 'national consciousness' is a dogmatic formula that cannot survive serious scrutiny. This formula is not used when establishing the national development processes in many other nations in Europe that also had foreign educational institutions or foreign languages, which were instrumental in the so called Revival and liberation processes. That is why the use of the exogenous labeling or self-naming of the Macedonians as Serbs, Bulgarians or Greeks should be used with caution in contemporary historiography. These exogenous labels or self-naming can be used as an affirmation of national consciousness's only in the cases where the individuals left clear, unambiguous, records of their feelings of belonging to these (or others) national corps (especially in the cases where the individuals left precise data of belonging to a certain territory as their homeland). In the historical sources where there existed exogenous labeling or self-naming (as Bulgarians, Greeks or Serbians), much of the evidence shows that this represented the millet/church affiliation, and not some sort of "national self-determination". A particularity of Ottoman Macedonia was the church division of the Macedonian Slavic Orthodoxy, and not some kind of Macedonian - exclusive ethnic or national mixture of the population. Unfortunately, the problem continues to exist in various national Balkan historiographies and mythologies, which still keep to the equation 'millet=nation' for the $19^{\text {th }}$ and the beginning of the $20^{\text {th }}$ century in Ottoman Macedonia. 


\section{BIBLIOGRAPHY}

Ahsan Tewfik, Radspieler E.A., Türkisch-Arabisch-Deutsches Wörterbuch, Wien-Leipzig 1910.

Alagić Šukrija, Arapsko-Srpsko-Hrvatski Rječnikza izbor iz Kitabu Sireti Resulillahi, Troškom i Nakladom Zemaljske Vlade za Bosnu i Hercegovinu, 1913

Ağakay Mehmet Ali, Turkce Sözlük, Ankara 1966.

Anastasiou, Turkish-Greek Dictionary, http:/translation.babylon.com/turkish/millet/ [access: 27.07. 2012].

Aviv Efrat, Millet System in the Ottoman Empire, "Oxford bibliographies - Oxford University Press", http://www.oxfordbibliographies.com/view/document/obo-9780195390155/obo-97801953901550231.xml [access: 08.09.2017].

Babylon, Turkish-English Dictionary, http://translation.babylon.com/turkish/millet/ [access: 27.06. 2012].

Balakrishhnan Gopal (ed.), Mapping the Nation, London 1996.

Baranov H.K., Arabsko-Russkij Slovar', Moskva 1958 [Баранов Х.К., Арабско-Русский Словаръ,

Москва 1958].

Barth Fredrik, Ethnic groups and boundaries. The social organization of culture difference, Oslo 1969.

Baskalov A.N., Golubova N.P., Kamilieva A.A. et al., Türcç - Rusça Sözlük, Москва 1977 - Istanbul 1989 [Баскалов А.Н., Голубова Н.П., Камилева А.А. et al, Türcç - Rusça Sözlük, Москва 1977 Истанбул 1989].

Bianchi T.X., Vocabularie Français - Turc, A L'usage des interprètes, des commerçans, des navigateurs, et utres voyageurs dans le Levant, Paris 1831.

Bianchi T.X., Dictionnaire Français - Turc, A L'usage des interprètes, des commerçans, des navigateurs et utres voyageurs dans le Levant, Paris 1846.

Bianchi T.X., Kieffer J.D., Dictionnaire Turc - Français, A L'usage des interprètes, des commerçans, des navigateurs et utres voyageurs dans le Levant, Paris 1850.

Broude Benjamin, Foundation Myths of the Millet System, Christians and Jews in the Ottoman Empire: Functioning of a Plural Society: The Central Lands, eds. Benjamin Broude and Bernard Lewis, New York-London 1982, vol. 1-2.

Dayre J., Deanovic M., Maixner R., Hrvatskosrpsko-francuski rečnik, Zagreb 1960.

Develioğlu Ferit, Osmanica - Türkçe Ansiklopedic Lügat, Ankara 1984.

Dimitrovski T., Korubin B., Stamatovski T. (Koneski B.), Rečnik na makedonskiot jazik so srpskohrvatski tolkuvanja, Skopje 1961 [Димитровски Т., Корубин Б., Стаматовски Т. (Конески Б.), Речник на македонскиот јазик со српскохрватски толкувања, Скопје 1961].

English-Turkish online Dictionary-a Bilingual Dictionary from ESTACO, http://online.ectaco.co.uk/main. jsp;jsessionid=bc302c40d4a81315f581?do=e-services- (access: 27.07.2012).

Ergul F. Asli, The Ottoman Identity: Turkish, Muslim or Rum?, „Middle Eastern Studies” 2012, vol. 48, no. 4, p. 629-645.

Fiedler E. Grace, Partition Linguistic Identity and Language Standardization, in: On Macedonian Matters, From the Partition and Annexation of Macedonia in 1913 to the Present, a Collection of Essays on Language, Culture and History, München-Berlin-Leipzig-Washington 2015, p. 185-226.

Friedman Victor, Macedonian language and nationalism during the nineteenth and early twentieth centuries, „Balkanistica” 1975, vol. 2, p. 83-98.

Gaam Niki, The Making of a Legend - Redhouse, „The Turkish Daily News”, 25.10.2002.

Georgiev V.G., Bernar R., Ivanov I.N. et al., B 'lgarski etimologičen rečnik, Sofija 1986, vol. 3 [Георгиев В.Г., Бернар Р., Иванов И.Н. et al, Български етимологичен речник, София, 1986].

Gellner Ernest, Conditions of Liberty: Civil Society and its Rivals. New York 1994.

German-Turkish Dictionary. LingvoSoft free online German dictionary, http://www.lingvozone.com/ main.jsp?action=translation\&do=dictionary\&language_id... [access: 27.07.2012].

Gondicas Dimitri, Charles Issawi, Ottoman Greeks in the Age of Nationalism: Politics, Economy and Society in the Nineteenth Century, Princeton 1999. 
Hroch Miroslav, Social Preconditions of the National Revival in Europe, A Comparative Analysis of the Social Composition of the Patriotic Group among the Smaller European Nations, London-New York 1985.

Jordanovski Nikola, Some Considerations about the $19^{\text {th }}$ century National Revival in Macedonia, in: Miejsce Macedonii na Balkanach, Historia - Polityka - Kultura - Nauka, ed. Irena Stawowy-Kawka, Kraków 2005, p. 199-208.

Kamûs-ı Fransevî, Fransizca'dan Türkçe'ye Lügat, Istanbul 1896.

Kamus-i Türki, Istanbul 1317 (1899/1900).

Karpat H. Kemal, Millets and Nationality: The Roots of the Incongruity of Nation and State in the PostOttoman Era, in: Christians and Jews in the Ottoman Empire: Functioning of a Plural Society: The Central Lands, eds. Benjamin Broude, Bernard Lewis, New York-London 1982, vol. 1-2.

Ottoman Population Records and the Census of 1881/82-1893, ,International Journal of Middle East Studies" 1978, vol. 9, no. 3, p. 237-274.

Kiselinovski Stojan, Nacionalna struktura stanovništva Makedonije 1900-1913, „Časopis za suvremenu povijest" 1979, vol. 11, no 1, p. 67-79.

Kitromilides Paschalis, Imagined Communities and the Origins of the National Question in the Balkans, „European History Quarterly” 1989, vol. 19, p. 149-194.

Kolev Valerij, Kuluri Christina, Stefoska Irena, Balkanskite vojni, Istoriska čitanka 3, Skopje 2007 [Колев Валериј, Кулури Христина, Стефоска Ирена, Балканските војни, Историска читанка 3, Скопје 2007].

Langtolang.comDictionary, http://www.langtolang.com/?selectMenuLang=1\&txtLang=millet\&selectFro m-Englis [access: 27.06.2012].

Levy Avigdor, The Jews in the Ottoman Empire, Princeton 1994.

Lewis Bernard, The Political Language of Islam, Chicago 1988.

Ljorovski Vamvakovski Dimitar, „Kako ne narekuvase Grcija”. Političkata realnost i izumiranjeto na mitot za David i Golijat: Makedonija i Grcija na Balkanot, Skopje 2014, p. 30-37 [Љоровски Вамваковски Димитар, „Како не́ нарекуваше Гриија”. Политичката реалност и изумирањето на митот за Давид и Голијат: Македонија и Гриија на Балканот, Скопје 2014].

Mesrob K. Krikorian, Armenians in the service of the Ottoman Empire 1860-1908, London 1978.

Mitrova Makedonka, The Treaty of Bucharest and the Unresolved Balkan Issues, „Macedonian Historical Review" 2011, no 2, p. 235-254.

Muftic Teufik, Arapsko-Srpskohrvatski, Sarajevo 1973.

Naçi Ömer, Lügat-ı Sözlük, Istanbul 1891.

Ogly H.G. Kor, Piersidsko-Russkij i Rusko-Piersidskij Slovar', Moskva 1957 [Оглы Х.Г. Кор, ПерсидскоРусский и Руско-Персидский Словаръ, Москва 1957].

Ortayl1 İlber), Najdolgiot vek na Imperijata, Skopje 2009 [Ортајли Илбер, Најдолгиот век на Империјата, Скопје 2009].

Osmanova M.N., Dorri D.H., Kisielieva L.N., Piersidsko-Russkij Slovar', Moskva 1983, vol. 2 [Османова М.Н., Дорри Д.Х., Киселева Л.Н., Персидско-Русский Словаръ, Москва, 1983].

Özön Mustafa Nihat, Büyük, Osmanlica-Türkçe Sözlük, Istanbul 1965.

Palmer E. H., Concise Dictionary of the Persian Language eleventh impression, London 1931.

Pandev Dimitar, Voved vo makedonistikata, Skopje 2009 [Пандев Димитар, Вовед во македонистиката, Скопје 2009].

Pandevska Maria, The Term Macedonian(s) in Ottoman Macedonia: On the Map and in the Mind, „Nationalities Papers. The Journal of Nationalism and Ethnicity” 2012, vol. 40, no 5, p. 747-766.

Pandevska Maria, Tranziciite vo makedonskoto nacionalno-osloboditelno dvizenje: niz teorijata na Miroslav Hroch, in: Tranziicite vo istorijata i kulturata, Skopje 2008, p. 171-186 [Пандевска Марија, Транзициите во македонското национално-ослободително движење: низ теоријата на Мирослав Хрох, во: Транзициите во историјата и културата, Скопје 2008].

Periodizaciia velikogo vostočnogo krizisa 1875-1881, in: Balkanot i Rusija: Opštoto i specifičnoto vo itsoriskiot i kulturniot razvitok, Skopje 2010, p. 23-34 [Периодизачия великого восточного кризиса 
1875-1881, во: Балканот и Русија: Општото и специфичното во историскиот и културниот развиток, Скопје, 2010].

Pandevski Manol, Nacionalnoto prašanje vo makedonskoto osloboditelno dviženje 1893-1903, Makedonskoto osloboditelno delo vo XIX $i$ XX vek, Skopje 1987, 5 vols [Пандевски Манол, Националното прашање во македонското ослободително движење 1893-1903, Македонското ослободително дело во ХІХ и ХХ век, Скопје, 1987].

Papadopoulos Theodore, Studies and documents relating to the history of Greek Church and people under Turkish Domination, 1990.

Pouillon François (ed), Dictionnaire des orientalistes de langue française, Paris 2008.

Poutignat Philippe, Streiff-Frenart Jocelyne, Théories de l'Ethnicité, Paris 1995.

Quentin Skinner, Meaning and Context: Skinner Quentin and his critics, Cambridge 1988.

Redhouse James, A Turkish and English Lexicon, Constantinople 1890.

Said Edward, Orientalism, New York 2003.

Sami Şemseddin, Kamûs-ı Fransevî, Türkçe'den Fransizca'ya Lügat, Istanbul 1883.

Schull F. Kenet, Identity of the Ottoman Prison Surveys of 1912 and 1914, „International Journal of Middle East Studies" 2009, vol. 41, no 3, p. 365-367.

Shaw J. Stanford, The Ottoman Census System and Population, 1831-1914, „International Journal of Middle East Studies" 1978, vol. 9, no 3, p. 326.

Shkaljic Abdulah, Turcizmi u srpskohrvatskom jeziku, Sarajevo 1989.

Skok Petar, Etimologijski Rječik Hrvatskog ili Srpskog Jezika, Zagreb 1972, vol. 2.

Tanner Arno, The Forgotten Minorities of Eastern Europe: The History and Today of Selected Ethnic Groups in Five Countries, Helsinki 2004.

Tolovski D. (ed. Tolstogo N.I.), Makiedonsko-Russkij slovar', Moskva 1963 [Толовски Д. (ed. Толстого Н.И.), Македонско-Русский Словаръ, Москва 1963].

Turkish-German Dictionary, http://translation.babylon.com/turkish/millet/ [access: 27.06.2012].

Ursinus Michael, Zur Diskussion um "Millet" im osmanischen Reich, "SüdostForschungen" 1989, vol. 48, p. $195-207$.

Vančev Nikola, Galbov Galb, Klasov Genčo, Tursko-b’lgarski rečnik, Sofija 1952 [Ванчев Никола, Гълъбов Гълъб, Класов Генчо, Турско-български речник, София 1952].

Wehr Hans, Arabisches Wörterbuch, für die Schriftsprache der Gegenwart, Veb Otto Harraassowitz, Leipzig 1956.

Yildiz M. Turkish-French Dictionary, http://ranslation.babylon.com/turkish/to-french/millet/ [access: 27.06.2012].

Yosmaoğlu Ipek, Counting Bodies, Shaping Souls: the 1903 Census and National Identity in Ottoman Macedonia, „International Journal for Middle East Studies” 2006, vol. 38, p. 55-77.

Zargan Turkish Glossary, http://www.zargan.com/sozluk.asp?Sozcuk=millet\&DisplayLang=2 [access: 27.06.2012).

Zenker Julius Theodor, Dictionnaire turc-arabe-persan [Türkisch-arabisch-persisches Handwörterbuch], Leipzig 1866.

Zundhausen Holm, Istorija Srbije od 19. do 20. Veka, Beograd 2009. 